\title{
Understanding the Current Energy Paradigm and Energy System Models for More Sustainable Energy System Development
}

\author{
Nathalie Spittler ${ }^{1,2, *(\mathbb{D}, \text { Ganna Gladkykh }}{ }^{1,2}$, Arnaud Diemer ${ }^{2}{ }^{-1}$ and Brynhildur Davidsdottir ${ }^{1}$ \\ 1 Department of Life and Environmental Sciences, University of Iceland, Reykjavik 101, Iceland, \\ Sæmundargata 2, 101 Reykjavík, Iceland; ganna.gladkykh@uca.fr (G.G.); bdavids@hi.is (B.D.) \\ 2 Department of Economics, University of Clermont Auvergne, 63000 Clermont Ferrand, France; \\ diemera@aol.com \\ * Correspondence: nas14@hi.is; Tel.: +43-650-790-8353
}

Received: 26 March 2019; Accepted: 17 April 2019; Published: 25 April 2019

\begin{abstract}
This study contributes to a better understanding of where to place different energy modelling tools and support better decision-making related to the sustainable development of energy systems. It is argued that through the connection of the energy field and the field of sustainable development, the current energy paradigm-encompassing economic, environmental and social aspects-has emerged. This paper provides an analysis of different categories of existing energy system models and their ability to provide answers to questions arising from the current energy paradigm formulated within this study. The current energy paradigm and the relevant questions were defined by conducting conceptual framework analysis. The overarching question of the current paradigm asks how different energy pathways impact on the (sustainable) development of the energy system and overall (sustainable) development globally and nationally. A review of energy system models was conducted to analyse what questions of the current energy paradigm are addressed by which models. The results show that most models address aspects of the current energy paradigm but often in a simplified way. To answer some of the questions of the current energy paradigm in more depth and to get novel insights on sustainable energy system development, it might be necessary use complementary methods in addition to traditional energy modelling methodological approaches.
\end{abstract}

Keywords: energy paradigm; sustainability; energy system models

\section{Introduction}

Energy has been at the centre of political and scientific debate for many centuries. In line with these debates, energy models representing energy systems have been developed. The energy system directly and indirectly interacts with economic, social and environmental systems. Through these interactions the systems influence the (sustainable) development of each other [1]. Energy is a central driver for economic and social development as well as environmental and climate issues. Today, with the emergence of the sustainability debate and considering the growing importance of the energy system in reaching multiple sustainable development goals, it is necessary to explore to what extent existing energy models are in accordance with the different aspects of the current views on the role of energy systems. In this paper these views are referred to as the current energy paradigm. No recent and comprehensive definition of the current energy paradigm exists, despite some earlier studies referring to an emerging or new energy paradigm [2,3]. While many energy model reviews exist (e.g., [4-7], so far none of them has been connected to the current energy paradigm. The aim of this study is to bridge this gap. 
Energy modelling has a long history and often supports decision-making in energy system planning. The first simple linear programming energy models were developed in the 1960s. Since then, many more have been developed [6]. One category of energy models is that of energy system models. An energy system can be defined as the process chain (or a subset of it) from the extraction of primary energy to the use of final energy to supply services and goods [8]. In other words, an energy system encompasses the "combined processes of acquiring and using energy in a given society or economy" [9]. Therefore, in this study all models, which focus on energy production and usage in the system, including the society or the economy, are referred to as energy system models.

In aiming to understand what kind of energy models are needed today to help answer the most important questions related to energy system development in the light of the current energy paradigm and overall sustainable development in the context of the sustainable development goals (SDGs) [10,11]. This paper aims to develop two main points:

1. The formulation of the current energy paradigm and related questions.

2. Analysis of existing energy system models used for assessing and decision making in energy system development, specifically focusing on what models are able to answer which questions.

In order to help achieve sustainable development objectives energy models as supporting tools should be able to answer a variety of questions that go beyond purely technological advancement of energy systems [7]. This includes energy relevant aspects of the SDGs [12] and other biophysical and socio-economic ones (e.g., [13-17]). Hence, the practical implications of this paper are:

1. Support in choosing the most relevant model for investigating and understanding a particular issue.

2. Identifying gaps between the capabilities of existing energy models and requirements of the current energy paradigm facilitates improvement of existing energy system models.

3. Point one and two, individually or combined, can facilitate better application of models for decision-making related to the development of energy systems.

Section 2 describes the research method. In Section 3 the current energy paradigm is defined. In Section 4 the models are analysed. This includes a description of the model categories, examples for each of them and exploration of the question how the existing models relate to the current energy paradigm. This is followed by a discussion and critical reflection of the findings in Section 5. Finally, the conclusion presents a summary of the main findings in Section 6.

\section{Method}

To answer the question to what extent current energy system models are able to answer the questions of the current energy paradigm, a literature and model review was carried out. First, the relevant literature for defining the current energy paradigm and, second, selected models and their documentation were reviewed. The current energy paradigm is defined by following the procedure of the conceptual framework analysis presented in Reference [18]. This analysis is based on eight phases, which are carried out iteratively and among others includes mapping data sources, defining concepts and validation [18]. As suggested in Reference [18] selected data sources span a range of text types and disciplines including the following: for supporting the paradigm part, Kuhn's [19] theory of paradigms was applied. The definition of the new view on energy systems was derived from mainly two types of literature: (i) texts international documents dealing with energy in the context of sustainable development, such as UN reports and international meeting or session reports [10,20-31] (ii) studies on sustainability and energy relevant to the broader energy system, including literature from different disciplines on the resource, environmental, economic and social aspects of the energy system $[3,6,13,15-17,32-55]$. The concepts identified within the literature were categorized and later integrated [18]. This resulted in a number of core concepts, constituting the current energy paradigm. In this paper, the identified and integrated concepts are represented as questions that arise from the 
current energy paradigm (see Section 3 Theory-The current energy paradigm). This provides the basis for assessing what models are able to provide answers to which questions arising from the current energy paradigm.

To obtain information on energy (system) models, first an initial search for energy model reviews conducted within the last 15 years was carried out, which resulted in a total of thirteen energy model reviews that were explored. Following this, the model reviews were narrowed down to those that explicitly dealt with energy system models as defined in the introduction. This led to seven main reviews covering 55 models (i.e., [6,7,51,56-59]). These were used for gaining preliminary insights into the models and modelling practices of energy system modelling as defined above. Following the analysis of the reviews, a total of fourteen models were reviewed in more detail (see list below). Based on prior reviews $[6,7,57,60]$ and the models' manuals, it was decided to categorize the models into top-down, bottom-up and hybrid models (more details in Section 4 Model analysis). Each of the categories encompasses several subcategories of modelling techniques (e.g., econometric, linear optimization).

Furthermore, due to the increased importance of energy in the field of sustainable development, energy plays a substantial role in models generally concerned with the assessment of sustainable development. Hence, it is considered important to, additionally to the energy system models, also include other assessment models that contain a substantial energy module. A total of seven (LEAP (the Long range Energy Alternatives Planning system) [61]; Threshold21 [62]; IMAGE (Integrated Model to Access Global Environment) [63]; FELIX (Functional Enviro-economic Linkages Integrated neXus) [64]; C-Roads [65]; DICE (Dynamic Integrated model of Climate and the Economy) [66]; REMIND (Regional Model for Investment and Development) [67]) of those models were reviewed.

The common features of each model group and the chosen models were investigated to identify how each of them addresses the questions raised by the current energy paradigm. In order to complement the general findings about the model groups, the results regarding the chosen models of each category are described in more detail. The exemplar models chosen for each category are distinct in their modelling characteristics and being representative for the different model categories. Additional criteria were the frequency of references to the energy systems models in the studied literature reviews and the policy relevance of these models. All of the chosen models are used in a policy-making context at a national, regional or international level. The models are:

Bottom-up

- $\quad$ MARKAL [68]

- $\quad$ TIMES [69]

- PRIMES [70]

- MESSAGE [71]

- WEM [72]

Top-down

- $\quad$ GEM-E3 [73]

- $\quad$ NEMS $[74,75]$

Hybrid

- MESSAGE-MACRO [76]

- MESSAGE-MAGICC [77]

- MESSAGE-Access [78]

- En-Roads $[79,80]$

Other assessment models 
- $\quad$ LEAP [61]

- Threshold21 [62]

- IMAGE [63]

- REMIND [67]

\section{The Current Energy Paradigm and Arising Questions}

In the Oxford English dictionary a scientific paradigm is referred to as "a world view underlying the theories and methodology of a particular scientific subject." This relates to Kuhn [19] who defines it as a set of basic concepts and experimental practices of a scientific discipline. According to Kuhn, a paradigm is not necessarily explicitly formulated and can be implicit revealing itself through the assumptions shared by a disciplinary community. A central element of Kuhn's theory is that of a paradigm shift, which is defined as a process of changing from one set of concepts (assumptions) to another within a discipline.

There are three main questions that this section seeks to explore: (1) What is meant by energy paradigm? (2) Why has the energy paradigm changed? (3) How can the current energy paradigm be defined?

In this paper, the energy paradigm is defined as a set of explicit and implicit assumptions about the energy system. Whether or not energy studies can be related to a scientific discipline [81], Kuhn's theory of paradigm shift is applicable, if energy is seen as a field of study associated with a set of explicit and implicit assumptions. Despite Kuhn's discussion of the paradigm shift mainly in the context of natural sciences, his concept has been used in many other contexts since his book was published, also in the energy field [2,82]. According to Kuhn, new knowledge and crises can drive paradigm change. The current energy system faces several challenges on the social and environmental sphere, which can be understood as crises as well as technological advancements and a new political agenda have been drivers of change $[12,14,49,50]$. Changes in fundamental assumptions about the energy system eventually define the way it is designed in reality. An energy system paradigm shift has occurred several times. The development of the current one is explained through to the emerging role of energy in the sustainable development debate and addressed challenges within theoretical research on energy [1].

To respond to the second question, a historical overview of the events and developments leading to the change of the energy paradigm is provided in Table 1. The relevant events, debates and corresponding literature for sustainable development (left column) and energy (right column) are displayed. In the middle column, the concepts derived from those two columns are presented. The concepts were obtained by conducting conceptual framework analysis (see Section 2 Method).

By integrating and synthesizing the concepts in Table 1 the answer to question number three (i.e., How can the current energy paradigm be defined?) is developed. The current energy paradigm can be described as the following: Energy is central for sustainable development and the goal of sustainable development, as defined in the Brundtland report, is central for the current energy paradigm. Three consequential aspects stem from this: (i) energy is essential for continuous socio-economic development and well-being; (ii) the facilitation of energy should not threaten any generations' quality of life and therefore it needs to stay within all environmental limits; possible future environmental impacts on the energy system need to be considered; and (iii) resource limitations for fossil fuels and for renewable energies need to be accounted for.

The main question arising from the current energy paradigm is "How do different energy system pathways impact (sustainable) development of the energy system and overall (sustainable) development globally and nationally?". The concepts presented in Table 1 translate into questions arising from the current energy paradigm presented in Table 2: 
Table 1. Historical overview of the events and developments leading to the change of the energy paradigm and identified concepts (This table is based on a review of the following references: $[3,6,10,13,15-17,20-55])$

\begin{tabular}{|c|c|c|c|}
\hline Year & Sustainable Development & Concepts & Energy \\
\hline $1970 s$ & $\begin{array}{l}\text { Limits to Growth and WORLD3 model } \\
\text { Conference of the Human Environment in } \\
\text { Stockholm, Sweden }\end{array}$ & $\begin{array}{l}\text { Limits of fossils and their implications } \\
\text { Environmental impact } \\
\text { Energy security }\end{array}$ & $\begin{array}{c}\text { Oil crisis } \\
\text { Hubbert curve } \\
\text { Establishment of IEA } \\
\text { Establishment of OPEC } \\
\text { Energy Modelling Forum establishment }\end{array}$ \\
\hline 1980s & $\begin{array}{l}\text { Brundtland report } \\
\text { Creation of IPCC }\end{array}$ & Sustainable development & $\begin{array}{l}\text { World Energy Council establishment } \\
\text { Concept of the cost of conserved energy and energy } \\
\text { supply curves }\end{array}$ \\
\hline 1990s & $\begin{array}{c}\text { United Nations Conference on Environment and } \\
\text { Development in Rio, Brazil } \\
\text { Signing of UNFCCC } \\
\text { Agenda } 21 \\
\text { 1st IPCC report }\end{array}$ & Climate change & $\begin{array}{l}\text { Merge of energy and climate research } \\
\text { Energy researchers contribution to Special report on } \\
\text { Emission Scenarios } \\
\text { Global Energy Perspectives book }\end{array}$ \\
\hline 2000s & $\begin{array}{c}\text { MDGs } \\
\text { 9th Session report of UN Commission of Sustainable } \\
\text { Development } \\
\text { World Summit on Sustainable Development } \\
\text { Kyoto protocol } \\
\text { Creation of EU ETS }\end{array}$ & $\begin{array}{l}\text { Energy is central for sustainable development } \\
\text { Link between energy and socio-economic } \\
\text { development (incl. energy relation to poverty, } \\
\text { urbanization, population dynamics) } \\
\text { Cross-scale energy systems impacts } \\
\text { (national/regional impact on global and vice versa) }\end{array}$ & $\begin{array}{c}\text { IAEA, IEA, UNDESA, } \\
\text { Eurostat and EEA indicator set } \\
\text { World Energy Assessment - Energy and the } \\
\text { Challenge of Sustainability by UNDP } \\
\text { 1st EU energy action plan (20/20/20 targets) }\end{array}$ \\
\hline 2010s & $\begin{array}{c}\text { SDGs } \\
\text { Paris Agreement }\end{array}$ & $\begin{array}{l}\text { Short-term versus long-term goals } \\
\text { Synergies and trade-offs between different } \\
\text { development goals } \\
\text { Limits of renewables and their implications } \\
\text { Impact of climate change on energy system }\end{array}$ & $\begin{array}{l}\text { Launch of Sustainable Energy for All } \\
\text { SDG } 7 \\
\text { Critical material resource debate } \\
\text { Climate change mitigation strategies } \\
\text { Climate change adaptation strategies } \\
\text { Climate and energy justice debate } \\
\text { Deep Decarbonization Pathways Project }\end{array}$ \\
\hline
\end{tabular}


Table 2. Questions arising from the current energy paradigm.

\begin{tabular}{|c|c|c|}
\hline Number & Question & Explanation \\
\hline 1 & How does the energy system affect climate change? & $\begin{array}{l}\text { This question refers to the effect the energy system, from production (including resource harvesting) to } \\
\text { consumption, has on the climate. Hence, the model should provide greenhouse gas (GHG) emission } \\
\text { values as well as their implications in terms of climate change effects (e.g., degree Celsius increases). }\end{array}$ \\
\hline 2 & $\begin{array}{l}\text { What other negative environmental impacts of the energy system } \\
\text { exist? }\end{array}$ & $\begin{array}{l}\text { This question refers to the pollutants that are not directly influencing the climate but have more local } \\
\text { effects on the environment (e.g., water, land, air), for example, particulate matter, nitrogen oxides. }\end{array}$ \\
\hline 3 & How does climate change affect the energy system? & $\begin{array}{l}\text { This question refers to the potential feedbacks arising from climate change on the availability of } \\
\text { renewable resources due to changed weather conditions (e.g., solar radiation, changed precipitation } \\
\text { for hydropower). }\end{array}$ \\
\hline 4 & $\begin{array}{l}\text { What are the limits of fossil resource supplies and what are } \\
\text { their implications? }\end{array}$ & $\begin{array}{l}\text { This question refers to the scarcity and depletion of fossil fuels and how this influences the energy } \\
\text { system in terms of availability and cost. }\end{array}$ \\
\hline 5 & $\begin{array}{l}\text { What are the limits of renewable resources and what are } \\
\text { their implications? }\end{array}$ & $\begin{array}{l}\text { This question refers to temporal availability of renewables and to scarcity of materials needed for } \\
\text { harvesting technology and how this influences future renewable energy systems in terms of availability } \\
\text { and cost. }\end{array}$ \\
\hline 6 & How can a secure energy system be provided? & $\begin{array}{l}\text { This question refers to the short- and long-term supply. Hence, it is addressing the availability of } \\
\text { resources to meet the energy demand, considering the intermittencies for the short-term and potential } \\
\text { resource scarcities in the long-term. }\end{array}$ \\
\hline 7 & $\begin{array}{l}\text { How does the energy system affect socio-economic development } \\
\text { beyond GDP? }\end{array}$ & $\begin{array}{l}\text { This question refers to the effects that the energy system has on human development, including its } \\
\text { influence on health, affordability and poverty eradication. }\end{array}$ \\
\hline 8 & $\begin{array}{l}\text { How will near future energy system developments shape the } \\
\text { long-term future energy system and how do long-term future } \\
\text { goals impact on short-term developments? }\end{array}$ & $\begin{array}{l}\text { This question refers to the fact that achieving certain goals in the near future can have impacts in the } \\
\text { long-term and vice versa due to created path-dependencies and lock-ins. }\end{array}$ \\
\hline 9 & $\begin{array}{l}\text { What are the synergies and trade-offs between different energy } \\
\text { system development goals? }\end{array}$ & $\begin{array}{l}\text { This question refers to the fact that the energy system is interlinked with the social, environmental and } \\
\text { economic system. Different goals with regards to each of the systems exist. Hence, it is important to } \\
\text { understand how those goals relate to each other and whether they are conflicting or complimentary. }\end{array}$ \\
\hline 10 & $\begin{array}{l}\text { How does the development of the energy system of one } \\
\text { country/region affect global development? }\end{array}$ & $\begin{array}{l}\text { This refers to understanding whether the energy system development of a country/region can influence } \\
\text { another country's/region's development (e.g., distribution of scarce resources, climate effects). }\end{array}$ \\
\hline 11 & $\begin{array}{l}\text { How do global developments affect the development of the } \\
\text { energy system of a country/region? }\end{array}$ & $\begin{array}{c}\text { This question refers to the influence globally negotiated goals (e.g., climate, energy, poverty eradication) } \\
\text { might have on a country's/region's energy system development. }\end{array}$ \\
\hline
\end{tabular}




\section{Model Analysis}

Energy systems' structures represented in a number of existing energy models capture the assumptions about the energy systems they portray. Since the role of energy models is helping decision-making at different levels [57], it is important that the models can answer the questions resulting from the current energy paradigm. Thus, the modelling output can help feasible decision-making for energy systems' development.

The questions energy models aim to answer and the modelling tools have been constantly changing depending on the context of different historical periods and the thereby changing paradigm, advancement of knowledge and technologies. Hence, to explore to what extent the existing energy system models can answer the questions associated with the current energy paradigm defined in Part 3, the following aspects were analysed: (i) the methods used in energy models; (ii) the questions addressed in the models; (iii) the context in which the models were built. This will be discussed for every model (or family of models) within the three categories presented in the research design.

\subsection{Bottom-Up Models}

Bottom-up models aim to demonstrate the system's components in detail. In these models, structural elements are portrayed in a sophisticated manner using disaggregated data. Applying the bottom-up modelling approach to energy models means focusing on the technological complexity of the energy system. Bottom-up energy models normally ignore any interactions between the energy sector and other sectors of the economy. Hence, bottom-up models are also referred to as partial equilibrium models. For example, they seek for equilibrium in energy demand and energy supply. Bottom-up models are highly disaggregated. Therefore, due to data availability and complexity, it is hard to apply them to a large spatial scale (e.g., global). Such energy models are usually referred to as sophisticated engineering models and are based on simplified market behaviour assumptions, including rational behaviour of actors in the system $[6,7,57,60]$.

Due to their equilibrium seeking nature, which often leads to modelling the energy system as an optimization problem (e.g., MARKAL, TIMES, MESSAGE), those models can in theory address questions related to resource limitations well. Constraints are put on available resources, which limits their availability and impacts on market prices. This is done for fossil resources for all the models that were analysed in more detail (i.e., MARKAL, MESSAGE, TIMES, PRIMES). No resource constraints regarding the critical materials for renewable resources are addressed in these models. However, some explicitly address constraints for biomass availability (i.e., MESSAGE \& PRIMES). All of them consider intermittencies to some extent (e.g., capacity factors or time series) and have resource cost-supply curves for renewables. This means that those models, although in theory could provide answers to questions 4 and 5, only answer question 4 and partly address question $5[71,83]$.

Climate change questions (i.e., questions 1 and 3) are partly addressed in bottom-up models but only in a linear manner, neglecting feedback between the components. The models are able to estimate greenhouse gas (GHG) emissions based on the energy mix and if certain policies are in place they can to constrain $\mathrm{CO}_{2}$ emissions through price effects (e.g., $\mathrm{CO}_{2}$ tax, $\mathrm{CO}_{2}$ certificates). However, beyond this linear consideration of GHG-emissions, no feedback between the energy system and climate change is modelled in any of the models explored (i.e., MARKAL, MESSAGE, PRIMES, TIMES). Also, they usually do not consider any other environmental impacts associated with the energy system (i.e., question 2) $[68,69,71,83]$.

As bottom-up energy system models are based on equilibria approaches. In these models, there is no feedback between climate change and the energy system and no possibility to model synergies and trade-offs between multiple energy system development goals. Such goals can include providing a sufficient amount of energy, minimizing environmental impacts and securing a stable long- and short-term energy supply. Thus, question 9 is not addressed by these types of models. However, this becomes possible with hybrid/nexus models (see Section 4.3 Hybrid models). 
Regarding questions 10 and 11, models consider questions related to the impacts of global developments on national ones and vice versa, as MARKAL and TIMES can model energy systems at the local, regional and multinational levels. The MESSAGE model can represent the energy supply at national or global level. At the global level, MESSAGE aggregates the world into 11 regions.

Since bottom-up models are partial equilibrium ones, they only search for an optimal solution in the energy sector and do not address any aspects related to the overall socio-economic impacts of the energy system (i.e., question 7). However, one of the main focuses of some of the models in this group (e.g., MARKAL, TIMES, PRIMES) is energy system security. This means they answer question 6 within the boundaries of the assumptions on resource limitations. They do not fully account for the impacts of the limitations of renewables (i.e., question 5) on energy security.

It is argued that due to the technological innovation focus, bottom-up models can be applied for building long-term scenarios for the energy system but are not looking at the interaction between shortand long-term energy system developments (i.e., question 8) [60].

The characteristics presented above also reflect on how the models are used in decision-making. MARKAL and TIMES are used by numerous countries and organizations for energy planning at different geographical scales $[68,69]$. Both models belong to the linear programming-based optimization group using GAMS as a programming language. Their main objective is finding a combination of energy technologies ensuring energy security, energy affordability and reduction of $\mathrm{CO}_{2}$ emissions at the lowest possible costs. MESSAGE is another widely used energy optimization model [71]. It is often employed for determining cost efficient technological portfolios allowing for GHG emissions reduction.

PRIMES is another technology-rich partial equilibrium energy model. It looks for an equilibrium solution for energy supply, demand, cross-border energy trade and emissions in European countries. It is used by the European Commission as energy policy decision support tool. However, unlike the aforementioned engineering models, some relationships between variables in PRIMES are based on econometrics. Thus, they are derived from empirics rather than solely relying on economic theory. With regards to the current energy paradigm, the main difference and strength of PRIMES is a detailed presentation of energy supply and energy demand sectors, as well as the mechanism of energy price formation. PRIMES incorporates a variety of policy instruments that can test the effects of different regimes and regulations on energy markets [83].

Contrary to bottom-up optimization models discussed above, the World Energy Model (WEM) is a bottom-up simulation model. The WEM is a large-scale simulation model which is used for energy policy projections. The model covers the entire global energy system, which is divided into 24 regions and includes several main modules: energy demand, power generation, refinery and transformation, fossil fuel supply, $\mathrm{CO}_{2}$ emissions and investment [72].

In the WEM, the impact of the energy system on the climate is modelled in terms of emissions in both parts-energy supply and energy demand (question 1). No feedback from climate change to the energy system is present in the model (question 3). GHG emissions are modelled as the only environmental effect of the energy system (question 2). However, the model differs between GHGs (e.g., sulphur content). Resource limits for both fossil and renewable energy resources are integrated in the model in the form of dynamic cost-resource curves. Renewables are limited by regional resource capacities. No other limits for renewables, such as infrastructural materials, are available in the WEM assumptions (questions 4 and 5). Simulation of different sets of technological and investment solutions to secure region-by-region energy supply (including energy access provision for the regions undersupplied with energy) is one of the main focuses of energy scenarios produced (question 6). The World Energy Outlook 2017 [84] discusses the Sustainable Development Scenario produced by WEM, which includes three integrated sustainable development objectives corresponding to the goals of SDG 7 (affordable and clean energy), SDG 13 (climate action) and SDG 3 (good health and well-being). Exploration of trade-offs between achieving different development goals is part of the Sustainable Development Scenario (questions 7, 8, 9). Although the model's structure does not allow to assess country level effects, based on the available WEM documentation, it is difficult to say 
whether it is possible to identify trade-offs between regional and global energy system developments (questions 10, 11).

\subsection{Top-Down Models}

Top-down models aim to provide a bigger picture of the modelled system. Applying the top-down approach to energy system modelling usually implies that the energy system is part of a holistic economic system. This means that these models are focused on demonstrating interactions between different parts (sectors) of an economy rather than deeply analysing the systems' structural elements, such as energy technologies. They investigate how the energy sector interconnects with other sectors of the economy. They study overall macroeconomic performance and seek for a big systemic goal. Methods generally used for top-down energy models include macroeconomic and general economic equilibrium modelling based on econometrics. In this section, GEM-E3 and NEMS are discussed. NEMS can be classified as a modular hybrid model. It includes several supply and demand modules, combining technologically-detailed bottom-up modules with economic top-down ones [85]. However, in this paper, NEMS is classified as a top-down model. This is due to the fact that its modules are not used as individual models (see Section 4.3. on hybrids) and the model itself is widely used for macroeconomic projections, seeking to find general equilibrium across all sectors [86].

NEMS [74,75] is an economic and energy model developed by the Energy Information Administration of the US Department of Energy. The model seeks to understand the effects of alternative energy policies on the US economy by capturing the feedbacks between the energy sector and other sectors. One of the main focuses of the model is to investigate the interrelation between energy system development at the national and international level (i.e., questions 8, 10 and 11). Regarding energy resource scarcities (i.e., question 4), the only fossil fuel in NEMS for which natural resources depletion is explicitly addressed is shale gas [74].

Limits for renewable energy sources (i.e., question 5) in the model account for spatial and temporal resource availability. For solar energy, NEMS' assumptions acknowledge the dependency of solar technologies on natural resources but do not include it in the model's structure due to assumed abundance of those resources [87]. Climate change is not explicitly addressed in the model (i.e., questions 1 and 3). No sophisticated emissions sector is present but GHG emissions and other environmental pollutants (i.e., question 2) are included as a structural part of every economic sector, enabling tracking the impact of economic growth on emission targets. There are no socio-economic aspects beyond GDP, as well as the trade-offs between economic, social and environmental goals, addressed in NEMS (i.e., questions 7 and 9).

GEM-E3 [73] is a general equilibrium model which presents the world as a combination of 37 regions. It models the whole macro-economic system aggregated into 26 production sectors. As a general equilibrium model, GEM-E3 looks for simultaneous balance across all markets.

A large number of questions related to the current energy paradigm are addressed in GEM-E3. Question 1 is addressed by including a structure of energy system-caused emissions, which allows to track climate damage. However, the climate feedback to the energy system (question 3) is absent. Environmental impacts of the energy system beyond $\mathrm{CO}_{2}$ emissions (question 2) are integrated into the model's structure. Apart from the possibility of better assessing environmental damages, this structure allows for a detailed analysis of climate change policies.

Limits for fossil fuels (question 4) are addressed but limits on renewable energies (question 5) are only included as exogenously defined constraints. One of the main focuses of GEM-E3 is energy security (question 6), which is represented by several indicators in the model. GEM-E3 addresses the energy system's impact on socio-economic development beyond GDP (question 7) by looking, in particular, at air quality and health impacts [88]. Being focused on exploring the role of the energy system in overall sustainable growth paths, GEM-E3 to some extent addresses the question of how the currently existing energy system shapes the future energy system (question 8). Trade-offs between development and environmental damages (question 9) are not explicitly addressed in the model but 
the mechanism of decision rules related to abatement cost and environmental damages are modelled in detail. Questions 10 and 11 are addressed in GEM-E3 and global as well as regional development dynamics can be tracked by, for example, exploring the changes in bilateral trade.

GEM-E3 is used by the European Commission as a decision support tool for tax, climate, energy, transport and employment policies. In particular, it was used for the EU 2030 Climate and Energy Framework and for the EU's preparation for the COP21 negotiations [73].

\subsection{Hybrid Models}

Top-down and bottom-up energy models are often contrasted as two extremes - "pessimistic economic paradigm" and "optimistic engineering paradigm" [89]. Hybrid models try to address the limitations of both types of models by connecting bottom-up and top-down approaches. Thereby, they combine technology-rich and macroeconomic model structures.

"The whole should exceed the sum of its parts: integrating aspects and functionality from top-down and bottom-up modelling approaches results in 'hybrid' models, which may provide more insight than the individual models could on their own" [90]. This is one of the latest definitions of this hybrid models. They are composed of fully working individual models and comprise two or more separate models, which can be integrated with each other to different extents. A common distinction of hybrid models is made depending on the extent to which the models are linked. They can be soft-linked (i.e., no integration of models, only external exchange of input or output data) or hard-linked (i.e., integration of models, including their structures and endogenous data exchange). The category of modelling systems, which combine multiple modules, is added to the classification of hybrids. However, in this paper, this category is not included in the hybrid section (see Section 4.2. Top-down models). [90]

Hybrid models can use more than one modelling technique. Those can include macroeconomic modelling, general economic equilibrium, linear optimization and partial equilibrium $[7,60,91]$, as well as system dynamics.

Since hybrid models are not one coherent group of models but vary in their characteristics, it is difficult to generalize what questions related to the current energy paradigm are addressed by this model group and which ones are not. This depends on the models and indeed the techniques used to build the hybrid. Each of the hybrid models addresses a particular question, often relating different aspects of energy system development on different scales (e.g., the connection between large scale energy price developments and its impact on energy use and consumer health). Therefore, each model has certain strengths and weaknesses, as well as it makes it possible to address and answer different questions of the current energy paradigm. The following examples will illustrate the broad range of their scope.

MESSAGE-MACRO [76] is an energy partial equilibrium model connected to a general equilibrium macroeconomic model. The solution method of this model combines linear optimization for the MESSAGE module and non-linear optimization for the MACRO module. Inputs for the model are very detailed on the energy supply side (MESSAGE) and very aggregated for the energy demand side (MACRO). The main goal of this hybrid is examining the interrelations between energy supply costs as well as technologies and major macroeconomic parameters in order to provide the best short- and especially long-term policy. Hence, it is focused on addressing question 8 [76].

MESSAGE-MAGICC [77] is not a pure energy model but it is still seen as a relevant hybrid energy climate model. It is a hybrid that combines the bottom-up energy system structure with a more macro-level climate model structure. MESSAGE-MAGICC estimates the effects of the energy-use-caused GHG emissions on the global climate system; hence, its primary objective is providing answers to question 1. Outputs of this model, together with the other models, are used as inputs for assessments and scenario studies by the Intergovernmental Panel on Climate Change (IPCC), the World Energy Council (WEC) and other organizations. The MAGICC module represents the climate and is based on a global average energy balance equation integrating atmosphere and ocean climate dynamics [77]. 
MESSAGE-Access [78] also does not correspond to the commonly understood definition of a hybrid energy model and Access could be seen as a simple extension of MESSAGE. However, if a hybrid is broadly defined as two or more fully functioning individual models that produce more insightful results when combined [90], MESSAGE-Access can be counted as a hybrid. The Access module represents a choice of energy technologies in the residential sector. The output of MESSAGE-Access [78] looks at the consequences of a transition to clean cooking fuels and electricity in the poorest world regions and implications of this for the global energy supply. The model particularly looks at the costs of health, environmental and economic consequences of different energy transition pathways. Currently, MESSAGE-Access is used by the United Nations Secretary General's Sustainable Energy for All (SE4All) initiative aiming at meeting Goal 7 of the SDGs of clean and affordable energy [92]. By allowing for the assessment of access to modern energy and its related costs, in-house pollution and health implications of it, this model clearly addresses question 7 of the current energy paradigm. However, it still does not provide a full answer to this question, since the impact of the energy system on other related socio-economic indicators is not investigated (e.g., relation to poverty eradication). Furthermore, it looks at the connection between regional and global development, which relates to question 10 and 11 [78].

En-Roads $[79,80]$ is a feedback-driven global scale system dynamics model. It explores interrelations between the energy and the climate system on an aggregated level focusing on some areas, which are represented in more detail (e.g., technology, innovation, price mechanisms). The model allows simulating different scenarios to explore how taxes, subsidies, economic growth, energy efficiency, technological innovation, carbon pricing, fuel mix and other factors affect global carbon emissions and temperature. Therefore, it is possible to investigate synergies and trade-offs between different policies, which explicitly addresses question 9. Another insight the model provides relates to understanding of how today's decisions on energy policy will affect the energy and climate system in the long-term (i.e., question 1 and 8) [79,80].

Together, all these models make it possible to say that hybrid models and their methods address most of the relevant questions of the current energy paradigm. However, it is obvious that although hybrid models often provide answers to many of the questions posed, no individual model can provide answers to all of the relevant questions. Nevertheless, it is expected that if energy system models do not answer all the questions related to the current energy paradigm, they should provide comprehensive assumptions and reasoning for not dealing with them (e.g., if some of the questions are beyond the scope or data is missing).

\subsection{Energy in Other Assessment Models}

This group of models contains models that cannot be qualified as energy models but are, nevertheless, of interest.

Four models were selected to be discussed in this section: Threshold 21 [62], LEAP [61], IMAGE [63] and REMIND [67]. The first two are system dynamics models. Neither Threshold 21 nor LEAP are energy models. In fact, they are macroeconomic models. They are considered relevant for the current discussion because, despite being focused on overall system sustainability rather than on the energy system only, they integrate a substantial energy component in their structures. This is strongly in line with the current energy paradigm, which sees energy as one of the main contributors to all pillars of sustainable development.

Threshold 21 [62] is a national, country level model. It integrates economic, social and environmental aspects. The model is used for designing and supporting long-term development planning in developing countries based on the SDGs priorities (question 7, question 9) [93]. The structure of Threshold 21 does not have an elaborated climate module but it includes a GHG emission module connected to the technological, energy and production sectors (i.e., question 1). No feedbacks between energy sector and climate change are modelled. The environmental impacts of pollution are present in Threshold 21 (i.e., question 2). However, the documentation of the model does not illustrate how 
detailed the environmental impact sector is. The limits for any fossil or renewable energy sources (i.e., questions 4 and 5) are not explicitly mentioned in the model's documentation. Threshold 21 is particularly focused on the trade-offs and controversies between achieving different SDGs, looking for the best national sustainable development paths. The most valuable insights from the model's simulation relate to identifying the best policy mixes for sustainable development by finding leverages for synergetic policy interventions for an integrated approach. Many of the leverages of this kind relate to energy system development. However, since Threshold 21 is not an energy system model, it does not answer specific energy-system-related questions. In particular, there are neither energy security aspects (i.e., question 6) nor short-term versus long-term energy system developments (i.e., question 8) explicitly addressed in the model's structure. In terms of policy impact, the model is widely used in developing countries as a tool for supporting sustainable development. Since the model has a strong national focus, it does not give insights on the connections between the national and international sustainable development (i.e., questions 10 and 11). In general, the structure of Threshold 21 is adaptable and customizable to a particular country's needs and priorities additional questions related to the current energy paradigm can be addressed.

LEAP [61] models energy production, consumption and associated GHG emissions in all main sectors of an economy. Its original design implies that the model combines different methods (e.g., optimization, partial equilibrium) and allows for the optional use of connected components (e.g., energy, water use, land use). LEAP has flexible data requirements and allows simulations with different types of output depending on the selected methodologies. The model supports running cost optimizing energy production and consumption scenarios, for which the OSeMOSYS (The Open Source Energy Modelling System) optimization model is used. Currently LEAP is used in more than 190 countries as a tool for integrated energy planning and greenhouse gas mitigation assessment (i.e., question 1), as well as a tool for energy assessments and Low Emission Development Strategies. Additionally, LEAP incorporates land use and water constraints with regards to renewable resources, which addresses question 5, as well as it is possible to model the impacts of the energy system on the environment beyond climate change (i.e., question 2) [61].

IMAGE [63] and REMIND [67] stand out from other models, because they belong to the model group called Integrated Assessment Models (IAMs). IAMs were initially intended to bring together the dynamics of natural and social systems in order to have better understanding of how human activities impact on natural systems, with particular emphasis on climate change [94]. They have played a major role in the scenarios developed in IPCC reports [95]. Most IAMs contain an energy system structure as the principle component, since it is one the main contributor to climate change. The current generation of IAMs contain relatively complex social system modules and aim at answering a wider range of questions related to sustainable development. Several IAMs exist developed and are used for assessing sustainable system pathways, including for example the Global Change Assessment Model (GCAM) (e.g., [96]), the Asian-Pacific Integrated Model (AIM) (e.g., [97]), the Emission Prediction and Policy Analysis Model (EPPA) (e.g., [98]) and others (e.g., [99,100]). For the purposes of this study, IMAGE and Remind were chosen as a representative models of the group.

IMAGE is a global/multiregional simulation model, which implies exploring the simulation of alternative scenarios of human and natural system development in the long run. IMAGE has a detailed emissions module, which accounts for the emissions to air, water and soil from the energy and the agricultural sector (i.e., questions 1 and 2). Climate change is modelled as temperature and precipitation changes, which feedback to water availability and land systems. Therefore, even though no direct feedbacks from climate change to the energy system are modelled, those feedbacks are indirectly available for hydro- and bioenergy (i.e., question 3). On the level of technological choice, no feedback from water scarcity to energy decisions is considered. Long-term fossil resource limits on the regional level are modelled as cost-supply curves (i.e., question 4). In a similar manner limits for renewable energy sources are modelled. The only exception is bioenergy, its production is limited by land availability and is connected to the agricultural land use (i.e., question 5). Energy security 
(i.e., question 6) is addressed in the model through resource depletion, energy resource trade and energy resource diversity. In its scenarios IMAGE explores possible impacts of climate policy on energy security. GDP is the main economic indicator but additional aspects relevant to human development are in the model, such as pollution impact on health and inequality in the form of GINI coefficient (i.e., question 7). IMAGE is positioned more suitable for exploring the long-term rather than short-term dynamics of it (i.e., question 8). As for the synergies and trade-offs between different development goals, the latest version of IMAGE is explicitly driven by questions related to reaching multiple SGDs and associated policy trade-offs (i.e., question 9). However, most of the insights related to those trade-offs are focused on the interrelations between energy and agricultural sectors. Among the evident trade-offs there are the ones related to land use, fertilizers, emissions, use of groundwater and their impact on prices, undernourishment and health. IMAGE is structured as a multiregional (26 regions) model. Therefore, it is possible to explore how changes in one region affect the development in other regions and where driving factors for major global changes are located geographically. However, there are limits for examining country-specific trends and policy changes, since most of the countries are modelled as part of the bigger regions (i.e., questions 10 and 11).

REMIND is a global multi-regional model incorporating the economy, the climate system and a detailed representation of the energy sector [67]. The model's structure includes limits of non-renewable energy sources as well as potentials of renewable energies (i.e., questions 4 and 5). In addition to the primary energy resource limits, land use limits for energy system developments are taken into account. Dynamics of land use and agriculture are based on the MAgPIE [101] model. It is often coupled with REMIND to provide insights on the connection between the energy system and land use, which is especially relevant for bioenergy. The limits for the non-renewable energy resources are modelled in the form of the region-specific extraction cost-curves. Similarly, the limits for the renewable energies are modelled in REMIND as the maximum technical resource potentials in different regions. The feedback from climate change to energy resource availability is not modelled in REMIND (i.e., question 3). REMIND incorporates a sophisticated emissions sector which includes those of aerosols and ozone precursors (i.e., question 1). Also, additional land use $\mathrm{CO}_{2}$ and agricultural non- $\mathrm{CO}_{2}$ emissions are incorporated in the MAgPIE module. In addition to already mentioned environmental impacts considered a water sector is present in REMIND. It aims for accounting the water use associated with different energy technologies (i.e., question 2). The issue of energy security in terms of intermittencies of the renewable energy sources is addressed in the model structure in the form of a detailed energy storage sector (i.e., question 6). The social dimension and complexity of energy system development is not addressed in REMIND. Neither is socio-economic development beyond GDP, nor the trade-offs between energy system development and other development goals (i.e., question 7 and 9). Overall, social system projections are exogenous in REMIND and are based on SSPs [102]. Regarding the interplay between regional and global energy system dynamics, it is largely addressed by a detailed modelling of energy investment and trade (i.e., questions 10 and 11).

\section{Discussion}

The analysis shows questions addressed by different types of energy models. It is important to acknowledge that although a question might be addressed by some part of the model, it is not necessarily the case that the model provides a complete answer to the question (e.g., by including GHG emissions as an output parameter, it does not specify what the impact of the energy system's development on climate change dynamics is). Hence, many of the aspects are addressed but the extent to which the model answers the question needs to be considered more carefully. Table 2 provides an aggregated overview of the main strengths and weaknesses associated with different model types that have been derived from the literature and described in more detail above. Because models were built for different purposes it cannot be expected that one model all questions. Therefore, in the context of the current energy paradigm, it is important to understand what type of models are better at handling what questions and where there is room for improvement. 
While Table 3 gives a general view on the strengths and weaknesses of particular model types related to answering the questions related to the current energy paradigm, it is important to provide a more detailed summary of the models' analysis results.

The first and second question of the current energy paradigm concerning climate change is addressed in many energy models of different types. However, the way it is integrated in the structures of most models is not aimed at addressing feedbacks and complex interrelations between the energy system and the climate. The climate sector in the energy models is often presented in the form of a GHG emissions-accounting units, demonstrating atmospheric GHG emissions and concentrations caused by different energy mixes. By modelling the climate sector this way, energy models do not aim to address the impact of the energy system on the environment. The main goal of addressing GHG emissions in energy models is cost optimization. Every ton of GHG emissions in such energy models is associated with monetary cost, which is taken into account when considering total cost of energy production and use. Thus, minimizing GHG emissions in such models is driven by the logic of minimizing costs from the supply and the demand side. This consequently leads to reducing negative impacts on the climate. From the modelling perspective, the presence of GHG-emission modules in energy system models makes it possible to connect them to climate models to arrive at more sophisticated assessment results.

As for the question referring to environmental impacts beyond climate change (i.e., question 2), it is mainly addressed by hybrid models. This is due to their different focus in general, which is exploring the effects between different systems. Other assessment models are especially concerned with this type of question as they are more explicitly addressing nexus questions and environmental issues such as the impact of pollution, land use and/or water. These issues are also often addressed by regional projects and research [103]. Due to the increasing interest of the policy and scientific field in understanding individual issues and especially the nexuses between food, water and energy, their relevance in energy system planning is growing [104,105]. Hence, their role in energy system modelling is gaining more relevance $[48,106]$.

The questions concerning limits of natural resources (question 4 and 5) as defined by the current energy paradigm, which addresses the following two aspects: limits of fossil energy resources (e.g., oil, coal) and limits of renewable resources (i.e., needed for harvesting certain types of energy and resources themselves). The results show that it is common for energy models to address fossil energy resource scarcity. In fact, the question regarding fossil fuel limitations has already been asked in the past as part of the peak-oil debate $[38,107]$ and therefore answers to it are presented in all types of energy system models. Limits for renewable energy resources are addressed rarely and mostly for bioenergy, which is a stock-based renewable energy source. Usually, limits for solar or wind energy are modelled considering spatial and temporal aspects of sun and wind availability. As for the limits of resources, such as scarce materials (e.g., Neodymium) and for harvesting flow-based renewable energy (i.e., solar and wind energy), there are no energy system models addressing them among those that were investigated. However, other assessment approaches, which rely on more biophysical concepts such as stock-flow modelling [108], the GEMBA (Global energy modelling-a biophysical approach) [109] EROI based calculations [110] consider those aspects. Question 6 is often addressed in relation to question 4, as long-term security of the energy system depends on the availability of resources. This is addressed for fossil fuels (question 4) in most models but not for renewables and materials needed to harvest them (question 5). With regards to the short-term security, which refers to the intermittencies, this is only addressed by limiting the allowed renewable capacity but is not assessed in more detail. 
Table 3. Strengths and weaknesses of different model types.

\begin{tabular}{|c|c|c|}
\hline Model Type & Strengths & Weaknesses \\
\hline Bottom-up & $\begin{array}{l}\text { - detailed and technology-rich structure allows to incorporate various resource constraints, cost implications } \\
\text { of different technological developments and resulting emissions } \\
\text { national/regional modelling approach allows to assess interconnectedness between energy systems on } \\
\text { country/regional/global level }\end{array}$ & $\begin{array}{l}\text { - socio-economic aspects are addressed to a limited } \\
\text { extent and the assumptions about socio-economic } \\
\text { system are often simplified }\end{array}$ \\
\hline Top-down & $\begin{array}{l}\text { - broader scope makes it possible to examine feedbacks between the energy sector and other sectors of } \\
\text { the economy } \\
\text { - } \quad \text { holistic approach for modelling economic system allows for climate change policies' analysis } \\
\text { - socio-economic dynamics is modelled in relatively detailed manner }\end{array}$ & $\begin{array}{l}\text { - simplified representation of the energy system } \\
\text { makes it difficult to understand the implications of } \\
\text { the different energy technologies' development }\end{array}$ \\
\hline Hybrid models & $\begin{array}{l}\text { - flexibility of the modelling approach allows to combine different models with different orientations in } \\
\text { accordance with the research questions asked } \\
\text { - it is possible to use models for different questions without changing model itself/developing new model } \\
\text { - by combining bottom-up and top-down models the methodological limitations of both approaches can } \\
\text { be reduced } \\
\text { the approach is suitable for modelling different nexuses related to energy system (i.e., } \\
\text { water-energy, water-land-energy) } \\
\text { by combining bottom-up structures with macroeconomic structures models allow to examine } \\
\text { policy-making in the short- and especially in the long-term }\end{array}$ & $\begin{array}{l}\text { - the models' structures can be very complex, which } \\
\text { may make interpretation of the modelling } \\
\text { output difficult } \\
\text { connection of models of different scales and using } \\
\text { different modelling techniques can be a } \\
\text { time-consuming and } \\
\text { high-technical-skills-demanding process }\end{array}$ \\
\hline Other assessment models & $\begin{array}{l}\text { - } \quad \text { explicitly focused on overall system sustainability } \\
\text { - } \quad \text { explign allows for exploring energy system contribution to the diverse aspects of sustainable development } \\
\text { - } \quad \text { possible to model different nexuses relevant to energy system development } \\
\text { address a broad variety of environmental questions that allow to explore energy systems' impact beyond } \\
\text { climate changes }\end{array}$ & $\begin{array}{l}\text { - energy systems are modelled in a very simplified } \\
\text { manner, which does not allow to answer specific } \\
\text { energy-system-related questions }\end{array}$ \\
\hline IAMs & $\begin{array}{l}\text { - focus on exploring cost and benefits resulting from the interrelations between economic and climate } \\
\text { systems make them best suited for analysing climate change mitigation and adaptation policies } \\
\text { approach allows for freedom in coupling different models and nexuses depending on research } \\
\text { question needs } \\
\text { in many models the energy system structure is the principle component and is modelled in a } \\
\text { detailed manner } \\
\text { new generation of models contain relatively complex social system modules and aim at answering a wider } \\
\text { range of questions related to sustainable development }\end{array}$ & \\
\hline
\end{tabular}


The socio-economic aspect of the current energy paradigm is not addressed by bottom-up models as it is beyond their focus. It is mainly addressed by top-down and hybrid models. A more detailed review of models and tools that especially deal with rural electrification can be found in Reference [111]. Due to the nature of those aspects, socio-economic development factors, especially arising from rural electrification, are often dealt with in more detail on a smaller scale by qualitatively evaluating individual cases, for example [112] or analytically assessing and mapping the impacts of rural energy access and its effects $[16,113,114]$. However, the models often do not provide any answers concerning the socio-economic implications of the energy system beyond GDP. Hence, question 7 is only addressed and partly answered by few models.

It is possible to address the interrelation between long- and short-term developments when bottom-up and top-down models are connected, as each of them is focused on a different time scale (see Section 4.3 Hybrid models). Thereby, hybrids can provide answers to question 8 . Question 9. The synergies and trade-offs between different energy system goals (e.g., energy access vs. environmental implications), is addressed and in some respects answered mostly by hybrid models, as their focus is on looking at different components of the energy system and relations between them. However, the example of WEM, which addresses questions 7, 8 and 9 in the Sustainable Development Scenario, demonstrates the potential that bottom-up simulation models have for exploring the trade-offs between different system goals.

Questions 10 and 11, regarding energy system development on different scales (local, regional, national, global), are mainly addressed through the aspect of trade and overall resource availabilities of fossil fuels. Trade of different energy sources defines supply and demand dynamics, through this price is affected. Potentially, trade of resources needed for harvesting energy could also be included in the energy models' structures, influencing prices for different energy sources. However, as was mentioned before, natural resources needed for harvesting energy are not addressed in the investigated energy models at all.

The current paradigm as defined here will evolve and change over time. Due to the importance of energy and its role for sustainable development, as also shown by the multiple links of SDG 7 to the other SDGs, it is likely that this will continue to shape the energy paradigm [11]. This would imply more widespread calls for holistic analysis of energy systems, making multi-dimensional analysis the rule rather than the exception.

The main limits of this study arise from its research design, which implied analysing model categories and only a number of models as representative examples within each modelling category, rather than discussing a large number of individual models in detail. Lopion et al. for example analysed models with regards to their strengths and weaknesses focusing on environmental and technical aspects of models. However, in their analysis they did not encompass all aspects of the current energy paradigm [5]. Thus, future research may analyse an extended number of energy system and integrated assessment models in terms of their correspondence to the current energy paradigm.

\section{Conclusions}

The aim was to understand what kind of energy models are needed today to help answer the most important questions related to energy system development in light of the current energy paradigm and thereby, facilitate more sustainable (energy) system planning and development. This study, first, formulated the current energy paradigm and the questions arising from it. Second, the study analysed to what extent those questions are answered by current energy system models.

The current energy paradigm, as formulated in this study, arises from the link between energy and sustainable development. Thus, energy models that serve the purpose of helping decision-making in designing energy systems for sustainable development, should be able to answer the questions arising from this paradigm and the relevant questions for specific purposes.

Understandably, it was found that none of the models chosen to be analysed can answer all of the questions related to the current energy paradigm, because they were built for different purposes. 
However, most of the questions are to a bigger or lesser extent addressed by at least one of the energy models explored. Therefore, it is necessary to choose the right model for relevant questions in a specific context.

It was often difficult to make a clear distinction on whether or not a particular model answers or addresses the questions posed. However, there is clear evidence of aspects of the current energy paradigm that are most and least represented by existing energy models. Regardless of the scale or method of modelling applied, the natural systems' interrelation with the energy system is addressed in most of the models as well as fossil fuels resource limits and energy-system-caused GHG emissions. In contrast, the limits for renewable energy as well as the feedbacks from the climate to energy systems are not present. The reason for exclusion of these aspects may be caused by a high level of uncertainty of potential environmental and cost impacts.

The question of trade-offs and synergies between different energy systems goals (i.e., social, economic, environmental), which is especially important in the context of understanding the role of energy systems in sustainability pathways, is not explicitly addressed by energy models currently used for policy making. Still, there are models of a new generation that explicitly look at such sustainable development trade-offs and synergies. Those models, in spite of presenting the energy sector in a simplified manner, can bring interesting insights to the role of the energy system in sustainable development and can support the design of sustainable energy pathways.

Overall, this analysis showed that in order to better understand how to improve energy modelling tools and support better decision-making related to the sustainable development of energy systems, models need to be approached critically. Even though most models address aspects of the current energy paradigm, they might do so in a simplified way. It is necessary to reflect on the questions needed to be answered and in what way the model can help answer them. It is believed that in order to answer some of the questions of the current energy paradigm in more depth, it might be necessary to depart from traditional methodological approaches and ways of thinking and use complementary methods. It can be argued that discussion on it is relevant to a community of energy researchers and practitioners, including energy modelers and policy-makers as it influences their work.

Author Contributions: Conceptualization, G.G. and N.S.; methodology, N.S.; formal analysis, N.S. and G.G.; writing-original draft preparation, G.G. and N.S.; writing—review and editing, N.S. and G.G.; supervision, A.D. and B.D.

Funding: This project has received funding from the European Union's Horizon 2020 research and innovation programme under the Marie Skłodowska-Curie grant agreement No 675153.

Conflicts of Interest: The authors declare no conflict of interest.

\section{Acronyms and Abbreviations}

$\begin{array}{ll}\text { C-Roads } & \text { Climate Simulation Model } \\ \mathrm{CO}_{2} & \text { Carbon dioxide } \\ \text { DDPP } & \text { Deep Decarbonization Pathways Project } \\ \text { DICE } & \text { Dynamic Integrated model of Climate and the Economy } \\ \text { EEA } & \text { European Environment Agency } \\ \text { En-Roads } & \text { Energy Simulation Model } \\ \text { EROI } & \text { Energy Return on Investment } \\ \text { EU ETS } & \text { European Union Emission Trading System } \\ \text { EU } & \text { European Union } \\ \text { Eurostat } & \text { European Statistics } \\ \text { FELIX } & \text { Functional Enviro-economic Linkages Integrated neXus } \\ \text { GAMS } & \text { General Algebraic Modelling System } \\ \text { GDP } & \text { Gross Domestic Product } \\ \text { GEM-E3 } & \text { General Equilibrium Modelling for Energy-Economy-Environment } \\ \text { GEMBA } & \text { Global Energy Modelling-a Biophysical Approach } \\ \text { GHG } & \text { Greenhouse Gas }\end{array}$




$\begin{array}{ll}\text { GINI } & \text { Measure of statistical dispersion to represent income/wealth distribution } \\ \text { IAEA } & \text { International Atomic Energy Agency } \\ \text { IAM } & \text { Integrated Assessment Model } \\ \text { IEA } & \text { International Energy Agency } \\ \text { IMAGE } & \text { Integrated Model to Access Global Environment } \\ \text { IPCC } & \text { International Panel on Climate Change } \\ \text { LEAP } & \text { Long range Energy Alternatives Planning system } \\ \text { MAgPIE } & \text { Model of Agriculture Production and its Impact on the Environment } \\ \text { MARKAL } & \text { Market Allocation } \\ \text { MDGs } & \text { Millennium Development Goals } \\ \text { MESSAGE } & \text { Model for Energy Supply Strategy Alternatives and their General Environmental impact } \\ \text { MESSAGE-Access } & \text { MESSAGE Energy Access Model } \\ \text { MESSAGE-MACRO } & \text { MESSAGE Macroeconomic Model } \\ \text { MESSAGE-MAGICC } & \text { Model for the Assessment of Greenhouse-gas Induced Climate Change } \\ \text { NEMS } & \text { National Energy Modelling System } \\ \text { OPEC } & \text { Organization of the Petroleum Exporting Countries } \\ \text { OSeMOSYS } & \text { The Open Source Energy Modelling System } \\ \text { PRIMES } & \text { A computable price-driven equilibrium model of the energy system and markets for Europe } \\ \text { REMIND } & \text { Regional Model for Investment and Development } \\ \text { SDGs } & \text { Sustainable Development Goals (SDGs) } \\ \text { SE4All } & \text { Sustainable Energy for All } \\ \text { SSPs } & \text { Shared Socio-Economic Pathways Scenarios } \\ \text { TIMES } & \text { Integrated MARKAL-EFOM system } \\ \text { UN } & \text { United Nations } \\ \text { UNDESA } & \text { United Nations Department of Economic and Social Affairs } \\ \text { UNFCCC } & \text { United Nations Framework Convention on Climate Change } \\ \text { WEC } & \text { World Energy Council } \\ \text { WEM } & \text { World Energy Model }\end{array}$

\section{References}

1. Najam, A.; Cleveland, C.J. Energy and Sustainable Development at Global Environmental Summits: An Evolving Agenda. Environ. Dev. Sustain. 2003, 5, 117-138. [CrossRef]

2. Helm, D. The assessment: The new energy paradigm. Oxf. Rev. Econ. Policy 2005, 21, 1-18. [CrossRef]

3. Jefferson, M. Energy Policies for Sustainable Development. World Energy Assessment. In World Energy Assessment: Energy and the Challenge of Sustainability; UNDP: New York, NY, USA, 2000; pp. 415-447.

4. Ringkjøb, H.K.; Haugan, P.M.; Solbrekke, I.M. A review of modelling tools for energy and electricity systems with large shares of variable renewables. Renew. Sustain. Energy Rev. 2018, 96, 440-459. [CrossRef]

5. Lopion, P.; Markewitz, P.; Robinius, M.; Stolten, D. A review of current challenges and trends in energy systems modelling. Renew. Sustain. Energy Rev. 2018, 96, 156-166. [CrossRef]

6. Bhattacharyya, S.C.; Timilsina, G.R. A review of energy system models. Int. J. Energy Sect. Manag. 2010, 4, 494-518. [CrossRef]

7. Pfenninger, S.; Hawkes, A.; Keirstead, J. Energy systems modelling for twenty-first century energy challenges. Renew. Sustain. Energy Rev. 2014, 33, 74-86. [CrossRef]

8. IIASA. Global Energy Assessment (GEA); Cambridge University Press: Cambridge, UK, 2012. [CrossRef]

9. Jaccard, M. Sustainable fossil fuels: The unusual suspect in the quest for clean and enduring energy. Sustain. Foss Fuels Unusual Suspect Quest Clean Endur. Energy 2006, 35, 1-381. [CrossRef]

10. United Nations. Sustainable Development Goals. About Sustain Dev Goals 2018. Available online: https: //www.un.org/sustainabledevelopment/sustainable-development-goals/ (accessed on 28 November 2018).

11. Fuso Nerini, F.; Tomei, J.; To, L.S.; Bisaga, I.; Parikh, P.; Black, M.; Borrion, A.; Spataru, C.; Castán Broto, V.; Anandarajah, G.; et al. Mapping synergies and trade-offs between energy and the Sustainable Development Goals. Nat. Energy 2018, 3, 10-15. [CrossRef]

12. United Nations. Sustainable Development Goals. Goal 7 Ensure Access to Affordable, Reliab Mod Energy All 2018. Available online: https://www.un.org/sustainabledevelopment/energy/ (accessed on 27 August 2018).

13. Tvaronavičienè, M.; Prakapienè, D.; Garškaitè-Milvydienè, K.; Prakapas, R.; Nawrot, Ł. Energy Efficiency in the Long-Run in the Selected European Countries. Econ. Sociol. 2018, 11, 245-254. [CrossRef] 
14. IEA (International Energy Agency). Energy and Air Pollution-World Energy Outlook 2016 Special Report; IEA: Paris, France, 2016.

15. WWF. Critical Materials for the Transition to a Sustainable Energy Future; WWF: Gland, Switzerland, 2014.

16. Rosenthal, J.; Quinn, A.; Grieshop, A.P.; Pillarisetti, A.; Glass, R.I. Clean cooking and the SDGs: Integrated analytical approaches to guide energy interventions for health and environment goals. Energy Sustain. Dev. 2018, 42, 152-159. [CrossRef]

17. Kasperowicz, R. Economic growth and energy consumption in 12 European countries: a panel data approach. J. Int. Stud. 2015, 7, 112-122. [CrossRef]

18. Jabareen, Y. Building a Conceptual Framework: Philosophy, Definitions and Procedure. Int. J. Qual. Methods 2009, 8, 49-62. [CrossRef]

19. Kuhn, T.S. The Structure of Scientific Revolutions; University of Chicago Press: Chicago, IL, USA, 1970.

20. UN. Report of the United Nations Conference on the Human Environment; United Nations: Stockholm, Sweden, 1972.

21. Ephraums, J.J.; Jenkins, G.J.J. Climate Change 1992; Press Syndicate by the University of Cambridge: New York, NY, USA, 1992.

22. United Nations. Department of Public Information. The Millennium Development Goals, List of Millennium Development Goals; United Nations: New York, NY, USA, 2000.

23. Breidenich, C.; Magraw, D.; Rowley, A.; Rubin, J.W. The Kyoto Protocol to the United Nations Framework Convention on Climate Change. Am. J. Int. Law 1998, 92, 315. [CrossRef]

24. IAEG-SDGs. Final List of Proposed Sustainable Development Goal Indicators. Rep Inter-Agency Expert Gr Sustain Dev Goal Indic 2016: Annex IV; United Nations: New York, NY, USA, 2016; ISBN 9789241508483.

25. Economic and Social Council. Communication from the Commission to the European Parliament, the Council, the European Economic and Social Committee and the Committee of the Regions (20 20 by 2020 Europe's Climate Change Opportunity); United Nations: New York, NY, USA, 2008.

26. UN. Adoption of the Paris Agreement. Conference of the Parties: Twenty-First Session; United Nations: New York, NY, USA, 2015.

27. Cappelletti, G.; Ardizzone, S.; Bianchi, C.L.; Gialanella, S.; Naldoni, A.; Pirola, C.; Ragaini, V. Photodegradation of Pollutants in Air: Enhanced Properties of $\mathrm{Nano}^{-\mathrm{TiO}_{2}}$ Prepared by Ultrasound. Nanoscale Res. Lett. 2008, 4, 97. [CrossRef]

28. United Nations. Johannesburg Declaration on Sustainable Development; United Nations: Johannesburg, South Africa, 2002; pp. 24-27.

29. UN Commission on Sustainable Development. Report on the Ninth Session; United Nations: New York, NY, USA, 2001.

30. Commission for Social Development. The Current Global Crises and Their Impact on Social Development; United Nations: New York, NY, USA, 2009.

31. Greene, L.A. United nations framework convention on climate change. Environ. Health Perspect. 2000, 108. [CrossRef]

32. Ebinger, J.; Vergara, W. Climate Impacts on Energy Systems; The World Bank: Washington, DC, USA, 2011. [CrossRef]

33. Schaeffer, R.; Szklo, A.S.; Pereira de Lucena, A.F.; Moreira Cesar Borba, B.S.; Pupo Nogueira, L.P.; Fleming, F.P.; Troccoli, A.; Harrison, M.; Sadeck Boulahya, M. Energy sector vulnerability to climate change: A review. Energy 2012, 38, 1-12. [CrossRef]

34. Huang, B.N.; Hwang, M.J.; Yang, C.W. Causal relationship between energy consumption and GDP growth revisited: A dynamic panel data approach. Ecol. Econ. 2008, 67, 41-54. [CrossRef]

35. Stern Nicholas, H. The Economics of Climate Change: The Stern Review; Cambridge University Press: Cambridge, UK, 2007.

36. Stavytskyy, A.; Kharlamova, G.; Giedraitis, V.; Šumskis, V. Estimating the interrelation between energy security and macroeconomic factors in European countries. J. Int. Stud. 2018, 11, 217-238. [CrossRef] [PubMed]

37. Makarenko, D.; Streimikiene, D. Quality of life and environmentally responsible behaviour in energy sector. J. Int. Stud. 2014, 8, 58-67. [CrossRef]

38. Nashawi, I.S.; Malallah, A.; Al-Bisharah, M. Forecasting World Crude Oil Production Using Multicyclic Hubbert Model. Energy Fuels 2010, 24, 1788-1800. [CrossRef] 
39. Keeble, B.R. The Brundtland report: Our common future. Med. War 1988, 4, 17-25. [CrossRef]

40. Meier, A. What is the cost to you of conserved energy? Harv. Bus. Rev. 1983, 61, 36-37.

41. Meier, A.K.; Rosenfeld, A. Supply Curves of Conserved Energy. Energy 1982, 7, 347-358. [CrossRef]

42. Nakicenovic, N.; Jefferson, M. Global Energy Perspectives to 2050 and Beyond; World Energy Council and IIASA: Laxenburg, Austria, 1995.

43. Wanger, T.C. The Lithium future-resources, recycling and the environment. Conserv. Lett. 2011, 4, $202-206$. [CrossRef]

44. Sovacool, B.K.; Heffron, R.J.; McCauley, D.; Goldthau, A. Energy decisions reframed as justice and ethical concerns. Nat. Energy 2016, 1, 16024. [CrossRef]

45. Jenkins, K.; McCauley, D.; Forman, A. Energy justice: A policy approach. Energy Policy 2017, 105, 631-634. [CrossRef]

46. Biros, C.; Rossi, C.; Sahakyan, I. Discourse on climate and energy justice: a comparative study of Do It Yourself and Bootstrapped corpora. Corpus 2018, 18, 1-28.

47. Bataille, C.; Waisman, H.; Colombier, M.; Segafredo, L.; Williams, J. The Deep Decarbonization Pathways Project (DDPP): insights and emerging issues. Clim. Policy 2016, 16, S1-S6. [CrossRef]

48. IEA (International Energy Agency). Water Energy Nexus-Excerpt from the World Energy Outlook 2016; OECD/IEA publishing: Paris, France, 2016; p. 60. [CrossRef]

49. Steffen, W.; Sanderson, A.; Tyson, P.; Jäger, J.; Matson, P.; Moore, B., III; Oldfield, F.; Richardson, K.; Schellnhuber, H.J.; Turner, B.L.; et al. Global Change and the Earth System; Springer: Berlin/Heidelberg, Germany, 2005.

50. Modi, V.; McDade, S.; Lallement, D.; Saghir, J. Energy Services for the Millennium Development Goals; UNDP: New York, NY, USA, 2005.

51. Nakata, T.; Silva, D.; Rodionov, M. Application of energy system models for designing a low-carbon society. Prog. Energy Combust. Sci. 2011, 37, 462-502. [CrossRef]

52. UNDP. World Energy Assessment. In Energy and the Challenge of Sustainability; UNDP: New York, NY, USA, 2000.

53. Vera, I.; Langlois, L. Energy indicators for sustainable development. Energy 2007, 32, 875-882. [CrossRef]

54. Meadows, D.H.; Meadows, D.L.; Randers, J.; Behrens, W.W. The Limits to Growth, 1st ed.; Universe Books: New York, NY, USA, 1972.

55. Simmons, J. Materials Critical to the Energy Industry; BP: London, UK, 2011; pp. 6-7.

56. Jebaraj, S.; Iniyan, S. A review of energy models. Renew. Sustain. Energy Rev. 2006, 10, 281-311. [CrossRef]

57. Nakata, T. Energy-economic models and the environment. Prog. Energy Combust. Sci. 2004, 30, 417-475. [CrossRef]

58. DeCarolis, J.F.; Hunter, K.; Sreepathi, S. The case for repeatable analysis with energy economy optimization models. Energy Econ. 2012, 34, 1845-1853. [CrossRef]

59. Després, J.; Hadjsaid, N.; Criqui, P.; Noirot, I. Modelling the impacts of variable renewable sources on the power sector: Reconsidering the typology of energy modelling tools. Energy 2015, 80, 486-495. [CrossRef]

60. Hourcade, J.-C.; Jaccard, M.; Bataille, C.; Ghersi, F. Hybrid Modelling: New Answers to Old Challenges. Energy J. 2006, 27, 1-11. [CrossRef]

61. Heap, C. Long Range Energy Alternative Planning System-User Guide for Version 2008. Available online: https:/www.google.com.tw/url?sa=t\&rct=j\&q=\&esrc=s\&source= web\&cd=2\&ved=2ahUKEwjproSC5erhAhWPOnAKHfVrBM8QFjABegQIBhAC\&url=http\%3A\% 2F\%2Fwww.energycommunity.org\%2Fdocuments\%2FLEAP2011UserGuideEnglish.pdf\&usg= AOvVaw3ufN5ypeLXKVIa--H4oSz_ (accessed on 25 March 2019).

62. Millennium Institute. Introduction and Purpose of Threshold 21; Millennium Institute: Washington, DC, USA, 2016.

63. Stehfest, E.; van Vuuren, D.; Bouwman, L.; Kram, T. Integrated Assessment of Global Environmental Change with IMAGE 3.0: Model Description and Policy Applications; Netherlands Environmental Assessment Agency (PBL): The Hauge, Netherlands, 2014; ISBN 978-94-91506-71-0.

64. Walsh, B.; Rydzak, F.; Obersteiner, M.; Fritz, S.; McCallum, I. The Felix Model; IIAS: Laxenburg, Austria, 2017.

65. Sterman, J.; Fiddaman, T.; Franck, T.; Jones, A.; McCauley, S.; Rice, P.; Sawin, E.; Siegel, L. Climate interactive: the C-ROADS climate policy model. Syst. Dyn. Rev. 2012, 28, 295-305. [CrossRef] 
66. Nordhaus, W.D. The "DICE" Model: Background and Structure of a Dynamic Integrated Climate-Economy Model of the Economics of Global Warming; Yale University: New Haven, CT, USA, 1992.

67. Klein, D.; Mouratiadou, I.; Pietzcker, R.; Piontek, F.; Roming, N. Description of the REMIND Model; Potsdam Institute for Climate Impact Research: Potsdam, Germany, 2017.

68. Loulou, R.; Goldstein, G.; Noble, K. Documentation for the MARKAL Family of Models. 2004. Available online: http://www.etsap.org/tools.htm (accessed on 10 December 2018).

69. Loulou, R.; Remne, U.; Kanudia, A.; Lehtila, A.; Goldstein, G. Documentation for the TIMES Model: Part III; IEA Energy Technology Systems Analysis Programme (ETSAP), 2016. Available online: http://www.ieaetsap.org/web/Documentation.asp (accessed on 10 December 2018).

70. E3MLab. PRIMES Model, Version 6. Detailed Model Description. 2016. Available online: http://www.e3mlab. ntua.gr/e3mlab/PRIMESManual/ThePRIMESMODEL2016-7.pdf (accessed on 10 May 2018).

71. Messner, S.; Strubegger, M. User's Guide for MESSAGE III; IIASA: Laxenburg, Austria, 1995.

72. IEA. World Energy Model Documentation 2014; IEA: Paris, France, 2014; p. 54.

73. Capros, P.; van Regemorter, D.; Paroussos, L.; Karkatsoulis, P.; Fragkiadakis, C.; Tsani, S. GEM-E3 Model Documentation; Publications Office of the European Union: Luxemborg, 2013. [CrossRef]

74. EIA. Assumptions to the Annual Energy Outlook 2017; EIA: Paris, France, 2017.

75. EIA. The National Energy Modelling System: An Overview 2009; EIA: Paris, France, 2009.

76. Messner, S.; Schrattenholzer, L. MESSAGE-MACRO: Linking an energy supply model with a macroeconomic module and solving it iteratively. Energy 2000, 25, 267-282. [CrossRef]

77. Rao, S.; Keppo, I.; Riahi, K. Importance of Technological Change and Spillovers in Long-Term Climate Policy. Energy J. 2006, 27, 123-139. [CrossRef]

78. Pachauri, S.; Nagai, P. The IIASA Energy Access Tool (Energy-ENACT); IIASA: Laxenburg, Austria, 2012.

79. Siegel, L.S.; Homer, J.; Fiddaman, T.; Mccauley, S.; Franck, T.; Sawin, E. EN-ROADS Simulator Reference Guide; Technical Report; Climate Interactive: Washington, DC, USA, 2018.

80. En-ROADS. Climate Interactive. Available online: https://www.climateinteractive.org/tools/en-roads/ (accessed on 19 April 2018).

81. Park, M.; Liu, X. Assessing Understanding of the Energy Concept in Different Science Disciplines. Sci. Educ. 2016, 100, 483-516. [CrossRef]

82. Jefferson, M. Closing the gap between energy research and modelling, the social sciences and modern realities. Energy Res. Soc. Sci. 2014, 4, 42-52. [CrossRef]

83. E3Mlab. PRIMES Model-Version 6, 2016-2017; E3MLab: Athens, Greece, 2016.

84. IEA. World Energy Outlook 2017; OECD Publishing: Paris, France, 2017. [CrossRef]

85. Helgesen, P.I. Top-down and Bottom-up: Combining energy system models and macroeconomic general equilibrium models. Cent. Sustain. Energy Stud. Work Pap. 2013, 30.

86. Energy Information Administration. The National Energy Modelling System: An Overview 2009; Volume 0581; Energy Information Administration: Washington, DC, USA, 2009.

87. EIA. Renewable Fuels Module of the National Energy Modelling System: Model Documentation 2016; EIA: Paris, France, 2016.

88. Vrontisi, Z.; Abrell, J.; Neuwahl, F.; Saveyn, B.; Wagner, F. Economic impacts of EU clean air policies assessed in a CGE framework. Environ. Sci. Policy 2016, 55, 54-64. [CrossRef]

89. Grubb, M. Policy modelling for climate change. The missing models. Energy Policy 1993, 21, $203-208$. [CrossRef]

90. Holz, F.; Ansari, D.; Egging, R.; Helgesen, P.I. Hybrid Modelling: Linking and Integrating Top-Down and Bottom-Up Models; NTUA-EPU: Athens, Greece, 2016.

91. Giupponi, C.; Borsuk, M.E.; de Vries, B.J.M.; Hasselmann, K. Innovative approaches to integrated global change modelling. Environ. Model. Softw. 2013, 44,1-9. [CrossRef]

92. Osborn, D.; Cutter, A.; Ullah, F. Universal Sustainable Development Goals: Understanding the transformational challenge for developed countries. Univers. Sustain. Dev. Goals 2015, 1-24.

93. Bassi, A.M.; Shilling, J.D. Informing the US Energy Policy Debate with Threshold 21. Technol. Forecast. Soc. Chang. 2010, 77, 396-410. [CrossRef]

94. Verburg, P.H.; Dearing, J.A.; Dyke, J.G.; van der Leeuw, S.; Seitzinger, S.; Steffen, W.; Syvitski, J. Methods and approaches to modelling the Anthropocene. Glob. Environ. Chang. 2015, 39, 328-340. [CrossRef] 
95. Van Vuuren, D.P.; de Vries, B.; Beusen, A.; Heuberger, P.S.C. Conditional probabilistic estimates of 21st century greenhouse gas emissions based on the storylines of the IPCC-SRES scenarios. Glob. Environ. Chang. 2008, 18, 635-654. [CrossRef]

96. Thomson, A.M.; Calvin, K.V.; Smith, S.J.; Kyle, G.P.; Volke, A.; Patel, P.; Delgado-Arias, S.; Bond-Lamberty, B.; Wise, M.A.; Clarke, L.E.; et al. RCP4.5: A pathway for stabilization of radiative forcing by 2100. Clim. Chang. 2011, 109, 77-94. [CrossRef]

97. Masui, T.; Matsumoto, K.; Hijioka, Y.; Kinoshita, T.; Nozawa, T.; Ishiwatari, S.; Kato, E.; Shukla, P.R.; Yamagata, Y.; Kainuma, M. An emission pathway for stabilization at $6 \mathrm{Wm}-2$ radiative forcing. Clim. Chang. 2011, 109, 59-76. [CrossRef]

98. Monier, E.; Paltsev, S.; Sokolov, A.; Chen, Y.H.H.; Gao, X.; Ejaz, Q.; Couzo, E.; Schlosser, A.C.; Dutkiewicz, S.; Fant, C.; et al. Toward a consistent modelling framework to assess multi-sectoral climate impacts. Nat. Commun. 2018, 9, 660. [CrossRef]

99. Matsumoto, K.; Tachiiri, K.; Kawamiya, M. Evaluating multiple emission pathways for fixed cumulative carbon dioxide emissions from global-scale socioeconomic perspectives. Mitig. Adapt Strateg. Glob. Chang. 2018, 23. [CrossRef] [PubMed]

100. Matsumoto, K.; Tachiiri, K.; Kawamiya, M. Impact of climate model uncertainties on socioeconomics: A case study with a medium mitigation scenario. Comput. Oper. Res. 2016, 66, 374-383. [CrossRef]

101. Dietrich, J.P.; Bodirsky, B.L.; Humpenöder, F.; Weindl, I.; Stevanović, M.; Karstens, K.; Kreidenweis, U.; Wang, X.; Mishra, A.; Klein, D.; et al. MAgPIE 4-A modular open-source framework for modeling global land systems. Geoscience 2019, 12, 1299-1317. [CrossRef]

102. Kriegler, E.; Bauer, N.; Popp, A.; Humpenöder, F.; Leimbach, M.; Strefler, J.; Baumstark, L.; Bodirsky, B.L.; Hilaire, J.; Klein, D.; et al. Fossil-fueled development (SSP5): An energy and resource intensive scenario for the 21st century. Glob. Environ. Chang. 2017, 42, 297-315. [CrossRef]

103. Endo, A.; Tsurita, I.; Burnett, K.; Orencio, P.M. A review of the current state of research on the water, energy and food nexus. J. Hydrol. Reg. Stud. 2015. [CrossRef]

104. Dai, J.; Wu, S.; Han, G.; Weinberg, J.; Xie, X.; Wu, X. Water-energy nexus: A review of methods and tools for macro-assessment. Appl. Energy 2018, 210, 393-408. [CrossRef]

105. IPCC. Summary for Policymakers: IPCC Special Report on Renewable Energy Sources and Climate Change Mitigation; Cambridge University Press: Cambridge, UK, 2011.

106. Ackerman, F.; Fisher, J. Is there a water-energy nexus in electricity generation? Long-term scenarios for the western United States. Energy Policy 2013, 59, 235-241. [CrossRef]

107. Liebert, W.; Englert, M. Risiken der Uranproduktion und der Urannutzung-Risiken für die Nutzung der Kernenergie; IEWT: Vienna, Austria, 2015; pp. 1-26.

108. Busch, J.; Steinberger, J.K.; Dawson, D.A.; Purnell, P.; Roelich, K. Managing critical materials with a technology-specific stocks and flows model. Environ. Sci. Technol. 2014, 48, 1298-1305. [CrossRef]

109. Dale, M.; Krumdieck, S.; Bodger, P. Global energy modelling-A biophysical approach (GEMBA) Part 2: Methodology. Ecol. Econ. 2012, 73, 158-167. [CrossRef]

110. Murphy, D.J.; Hall, C.A. Energy return on investment, peak oil and the end of economic growth. Ann. N. Y. Acad. Sci. 2011, 1219, 52-72. [CrossRef]

111. Mandelli, S.; Barbieri, J.; Mereu, R.; Colombo, E. Off-grid systems for rural electrification in developing countries: Definitions, classification and a comprehensive literature review. Renew. Sustain. Energy Rev. 2016, 58, 1621-1646. [CrossRef]

112. Palit, D. Solar energy programs for rural electrification: Experiences and lessons from South Asia. Energy Sustain. Dev. 2013, 17, 270-279. [CrossRef]

113. Riva, F.; Ahlborg, H.; Hartvigsson, E.; Pachauri, S.; Colombo, E. Electricity access and rural development: Review of complex socio-economic dynamics and causal diagrams for more appropriate energy modelling. Energy Sustain. Dev. 2018, 43, 203-223. [CrossRef]

114. Collste, D. Policy coherence to achieve the SDGs: using integrated simulation models to assess effective policies. Sustain. Sci. 2017. [CrossRef]

(C) 2019 by the authors. Licensee MDPI, Basel, Switzerland. This article is an open access article distributed under the terms and conditions of the Creative Commons Attribution (CC BY) license (http://creativecommons.org/licenses/by/4.0/). 